\title{
Optimasi Alat Berat pada Pemindahan Tanah Mekanis (Studi Kasus Penyediaan Timbunan Tanah Pilihan Pada Pekerjaan Peningkatan Akses Jaringan Pipa Air Bersih Kabupaten Tanjung Jabung Barat, Booster Senyerang)
}

\author{
${ }^{1}$ Suhendra, 2 Annisaa Dwiretnani, ${ }^{3}$ Endika \\ 1,2Dosen Fakultas Teknik Universitas Batanghari Jambi \\ ${ }^{3}$ Mahasiswa Teknik Sipil Universitas Batanghari Jambi \\ Email : Suhendra_domas@yahoo.com
}

\begin{abstract}
Abstrak
Pekerjaan Penyediaan tanah timbunan pilihan untuk pembangunan booster Senyerang papa pekerjaan Peningkatan Akses Jaringan Pipa Air Bersih Kabupaten Tanjung Jabung Barat menggunakan alat berat yaitu satu excavator dalam pekerjaan galian material tanah dilokasi quarry dan dua dump truck untuk pengangkutan material tanah dari quarry ke lokasi penimbunan. Penelitian ini menganalisis produktivitas alat berat yang digunakan dalam penyediaan timbunan tanah pilihan dari quarry sampai ke lokasi penimbunan. Kemudian dilakukan optimasi berdasarkan produktivitas, jumlah alat dan biaya yang ditimbulkan. Hasil perhitungan kombinasi alat berat yang digunakan di lapangan menunjukkan belum optimalnya produktivitas excavator pada penyediaan timbunan tanah asli, dari quarry sejauh $11 \mathrm{~km}$ dari lokasi penimbunan sebanyak $1365,33 \mathrm{~m}^{3}$, terhadap produktivitas dump truck. Hasil penelitian mendapatkan optimalnya pekerjaan penyediaan tanah timbunan adalah tambahan jumlah dump truck sehingga menjadi lima unit. Optimasi yang dilakukan mempercepat waktu pengerjaan (menjadi tiga hari, dari semula delapan hari) dan menghasilkan pengurangan biaya sebesar Rp.6.455.000,-
\end{abstract}

Kata kunci: Optimasi, Alat berat, Excavator, Dump Truck, Produktivitas

\section{PENDAHULUAN}

Pekerjaan Peningkatan akses jaringan pipa air bersih Kabupaten Tanjung Jabung Barat tahun 2018 merupakan kelanjutan dari kegiatan sebelumnya pada tahun 2008-2010. Salah satu item pekerjaannya adalah pembangunan Booster Senyerang. Pada pekerjaan ini, dibutuhkan volume timbunan tanah pilihan untuk halaman yang volumenya $1365,33 \mathrm{~m}^{3}$.

Pada pelaksanaannya, penyediaan tanah timbunan untuk pekerjaan didominasi dengan peralatan mekanis. Dalam pekerjaan peningkatan akses jaringan pipa air bersih ini menggunakan bantuan alat berat berupa excavator dan dump truck. Penggunaan alat berat yang kurang tepat dengan kondisi lapangan, pekerjaan akan berpengaruh pada rendahnya produktivitas alat dan tidak tercapainya jadwal atau target yang sudah ditentukan.

Berdasarkan masalah tersebut maka penulis melakukan penelitian untuk menganalisa kapasitas, jumlah kebutuhan alat berat, dan waktu pengerjaan timbunan tanah pilihan pada pekerjaan tersebut dan kemudian dilakukan optimasi pada pekerjaan tersebut.

Optimasi menurut kamus besar bahasa Indonesia (optimalisasi) diartikan sebagai pengoptimalan, yaitu proses, cara, pembuatan untuk menghasilkan yang paling baru. Sedangkan optimasi berasal dari bahasa Inggris Optimization yang berarti optimal.(Maharany dan Fajarwati,2006). Pada penelitian ini, analisa optimasi diartikan sebagai suatu proses penguraian durasi pekerjaan untuk mendapatkan percepatan durasi yang paling baik (optimal).

Jumlah excavator yang dibutuhkan dalam suatu pekerjaan yaitu dengan rumus : (Rochmanhadi, 1985)

$\mathrm{n}=\frac{\mathrm{V}}{\mathrm{We} \times \mathrm{S} \times \mathrm{Q}}$

Keterangan :

$\mathrm{N}$ = Jumlah unit peralatan (unit) 
$\mathrm{V}=$ Volume pekerjaan $\left(\mathrm{m}^{3}\right)$

We $=$ Waktu efektif hari kerja (hari)

$\mathrm{S}=$ Standar jam kerja perhari (jam/hari)

$\mathrm{Q}=$ Produksi peralatan persatuan-satuan waktu $\left(\mathrm{m}^{3} / \mathrm{jam}\right)$

Jumlah dump truck dihitung yaitu dengan rumus : (Rostiyanti, 2002)

$\mathrm{m}=\frac{Q}{Q 1 \times n \text { (unit) }}$

Keterangan :

$\mathrm{m}=$ Jumlah unit dump truck

$\mathrm{Q}=$ Produksi alat excavator $\left(\mathrm{m}^{3} / \mathrm{jam}\right)$

$\mathrm{Q} 1$ = Produksi alat dump truck $\left(\mathrm{m}^{3} / \mathrm{jam}\right)$

$\mathrm{n} \quad=$ Jumlah unit excavator

Waktu pengerjaan volume tanah dihitung menurut rumus berikut : (Rostiyanti, 2002)

Waktu pengerjaan $=\frac{\text { Volume tanah }}{\text { (produktivitas alat } \mathrm{x} \text { jumlah alat) } \mathrm{x} \text { jam kerja }}$

Besarnya nilai asuransi dan pajak kepemilikan peralatan diambil rata-rata per tahun sebesar $0,2 \%$ dari harga pokok alat. Dengan rumus sebagai berikut :

$F=\frac{0,2 \% \times B}{W}$

Keterangan :

B : Harga pokok alat; Rp.

$\mathrm{W}$ : Jumlah jam kerja alat dalam satu tahun; jam

Perhitungan biaya pasti mengunakan rumus berikut :

$\mathrm{G}=(E+F) \frac{(\mathrm{B}-\mathrm{C}) \times \mathrm{D}}{\mathrm{W}}+\frac{\text { Ins } \mathrm{x}}{\mathrm{W}}$

Keterangan :

G : Biaya pasti per jam; Rp.

B : Harga pokok alat setempat; Rp.

C : nilai sisa alat (10\% dari harga pokok alat)

D : Faktor angsuran modal

E : Biaya pengembalian modal

$\mathrm{F}$ : Biaya asuransi dan pajak $(0,002 \times \mathrm{B}$ atau $0,02 \mathrm{C})$

$\mathrm{W}$ : Jumlah jam kerja dalam satu tahun

Faktor angsuran modal

$D=\frac{\mathrm{ix}(1+\mathrm{i})^{\mathrm{A}}}{(1+\mathrm{i})^{\mathrm{A}}-1}$

Biaya Pengembalian Modal $E=\frac{(B-C) \times D}{W}$

Keterangan :

A : Umur ekonomis alat; tahun

i $\quad$ : Tingkat suku bunga per tahun; \%

B : Harga pokok alat; Rp.

C : Nilai sisa alat; $\%$

W : Jumlah jam kerja alat dalam satu tahun; jam

Menurut Permen PUPR no. 28 tahun 2016, biaya operasional adalah biaya yang dikeluarkan pada saat menyewa alat berat. Biaya operasi terdiri dari :

\section{a. Biaya Bahan Bakar $(\mathbf{H})$}

$H=(12 \mathrm{~s} / \mathrm{d} 15) \% \times \mathrm{HP}$

Keterangan :

$\mathrm{H} \quad$ : Banyaknya bahan bakar yang dipergunakan dalam 1 (satu) jam; Liter/jam

HP : Horse Power, kapasitas tenaga mesin 
$12 \% \quad$ : Persentase untuk alat dalam pemakaian ringan

$15 \%$ : Persentase untuk alat dalam pemakaian berat

b. Biaya Pelumas (I)

Banyaknya minyak pelumas (termasuk pemakaian minyak yang lain serta grease) yang dipergunakan oleh peralatan yang dihitung dengan rumus dan berdasarkan kapasitas tenaga mesin.

$I=(2,5 s / d 3) \% \times H P$

Keterangan :

I : Banyaknya minyak pelumas yang dipakai dalam 1 (satu) jam; Liter/jam

HP : Horse Power, kapasitas tenaga mesin

2,5\% : Persentase untuk alat dalam pemakaian ringan

$3 \% \quad$ : Persentase untuk alat dalam pemakaian berat

\section{c. Biaya Bengkel $(\mathbf{J})$}

Besarnya biaya bengkel (wokshop) per jam dihitung dengan rumus sebagai berikut :

$\mathrm{J}=(6,25 \mathrm{~s} / \mathrm{d} 8,75) \% \times \mathrm{B} / \mathrm{W}$

Keterangan :

B : Harga pokok alat setempat; Rp.

W : Jumlah jam kerja alat dalam 1 (satu) tahun; Jam

$6,25 \%$ : Persentase untuk pemakaian ringan

$8,75 \%$ : Persentase untuk pemakaian berat

d. Biaya Perbaikan (K)

Untuk menghitung biaya perbaikan termasuk penggantian suku cadang yang aus dipakai rumus :

$\mathrm{K}=(12,5 \mathrm{~s} / \mathrm{d} 17,5) \% \times \mathrm{B} / \mathrm{W}$

Keterangan :

B : Harga pokok alat setempat; Rp.

W : Jumlah jam kerja alat dalam 1 (satu) tahun; Jam

$12,5 \%$ : Persentase untuk pemakaian ringan

$17,5 \%$ : Persentase untuk pemakaian berat

e. Upah Operator (L) dan Pembantu Operator (M)

Biaya operator tergantung dari tiap daerah, untuk menghitung biaya upah operator dan pembantu operator dipergunakan rumus berikut :
Operator
$=1$ orang/jam $\times$ OP 1
Pembantu Operator $\quad=1$ orang/jam x OP2

f. Biaya Operasional $(P)$

$\mathrm{P}=\mathrm{H}+\mathrm{I}+\mathrm{J}+\mathrm{K}+\mathrm{L}+\mathrm{M}$

Keterangan :

$\mathrm{H}$ : Biaya bahan bakar

I : Biaya minyak pelumas

$\mathrm{J}$ : Biaya bengkel

$\mathrm{K}$ : Biaya perbaikan

$\mathrm{L}$ : Biaya operator/driver

M : Biaya pembantu operator

Kapasitas produksi per jam (P)

$\mathrm{P}=\frac{\mathrm{q} \times 3600 \times \mathrm{E}}{\mathrm{Cm}}$

Keterangan :

$\mathrm{P}=$ Produktivitas per jam (m3/jam)

$\mathrm{q}=$ = Produksi per siklus (m3)

$\mathrm{E} \quad=$ Efisiensi kerja 
$\mathrm{Cm} \quad=$ Waktu siklus

\section{Waktu siklus}

$\mathrm{Cm}=$ Waktu gali + Waktu putar $\mathrm{x} 2+$ Waktu buang

Keterangan :

$\mathrm{Cm} \quad=$ Waktu siklus

\section{Produksi per siklus (q)}

$\mathrm{q}=\mathrm{ql} \times \mathrm{K}$

Keterangan :

$\mathrm{q}=$ Produksi per siklus $(\mathrm{m} 3)$

$\mathrm{ql} \quad=$ Kapasitas bucket

$\mathrm{K} \quad=$ Factor bucket

Kapasitas produksi per jam : $Q=\frac{V \times F a \times 60}{W D \times T s} m 3$

Keterangan :

$\mathrm{V}=$ Kapasitas bak; ton

$\mathrm{F}_{\mathrm{k}}=$ Faktor pengembangan bahan

$\mathrm{F}_{\mathrm{a}}=$ Faktor efisiensi alat

$\mathrm{D}=$ Berat isi material (lepas atau gembur); ton $/ \mathrm{m}^{3}$

$\mathrm{T}_{\mathrm{s}}=$ Waktu Siklus; menit

Waktu Siklus : $\mathrm{T}_{\mathrm{s}}=\mathrm{T}_{1}+\mathrm{T}_{2}+\mathrm{T}_{3}+\mathrm{T}_{4}$

Keterangan :

$\mathrm{T}_{1}=$ Waktu memuat

$\mathrm{T}_{1}=\frac{V \times 60}{D \times Q \text { exc }}$; menit

$\mathrm{T}_{2}=$ Waktu tempuh isi

$\mathrm{T}_{2}=\left(\frac{L}{V 1}\right) \times 60 ;$ menit

$\mathrm{T}_{3}=$ Waktu tempuh kosong

$\mathrm{T}_{3}=\left(\frac{L}{V 2}\right) \times 60 ;$ menit

$\mathrm{T}_{4}=$ Waktu lain-lain; menit

\section{METODE PENELITIAN}

Secara ringkas, penelitian ini bisa dilihat dari bagan alir penelitian berikut:

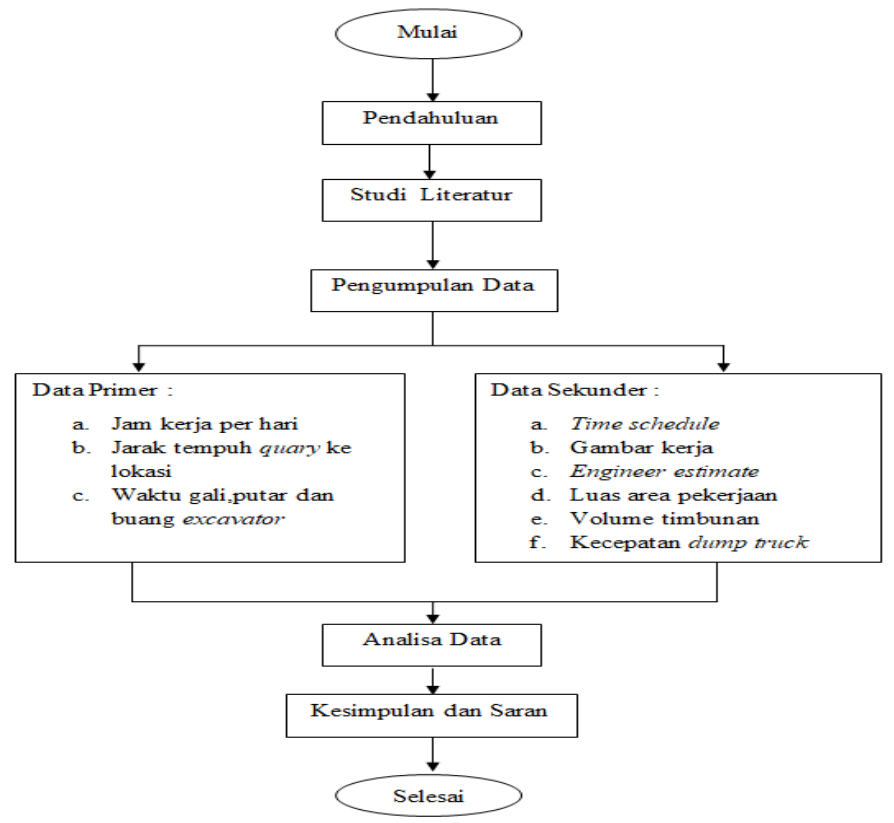

Gambar 1. Bagan Alir Penelitian 


\section{HASIL DAN PEMBAHASAN}

Volume pekerjaan timbunan tanah pilihan sebanyak $1365,33 \mathrm{~m}^{3}$ merupakan timbunan yang sudah dipadatkan. Quarry timbunan berupa lahan tanah asli. Sehingga faktor pengali volume untuk pekerjaan timbunan ini adalah 1,39 (Rochmanhadi, 1985). Selanjutnya volume timbunan dihitung berdasarkan volume tanah lepas/ gembur. Hasil perhitungan produktivitas excavator dan dump truck dapat dilihat pada table-tabel berikut.

Tabel 1. Perhitungan Kapasitas Produksi Excavator

\begin{tabular}{|c|c|c|c|c|c|}
\hline No & Uraian & Kode & Koef & Kuantitas & Satuan \\
\hline \multirow[t]{6}{*}{1} & Input Data & & & & \\
\hline & Volume timbunan : $1365,33 \times 1,39$ & & & 1897,81 & $\mathrm{~m}^{3}$ \\
\hline & Jam kerja efektif per hari & $\mathrm{Tk}$ & & 7 & jam \\
\hline & Waktu gali & & & 11 & detik \\
\hline & Waktu putar & & & 4 & detik \\
\hline & Waktu buang & & & 5 & detik \\
\hline \multirow[t]{10}{*}{2} & Alat berat Excavator & & & & \\
\hline & Kapasitas bucket & $\mathrm{ql}$ & & 0,91 & $\mathrm{~m}^{3}$ \\
\hline & Faktor bucket (tabel 2.6) & $\mathrm{K}$ & 0,8 & & $\mathrm{~m}^{3}$ \\
\hline & Engine rated power & HP & & 168 & \\
\hline & Efisiensi kerja (tabel 2.3) & $\mathrm{E}$ & 0,81 & & \\
\hline & $\begin{array}{l}\text { Produksi per siklus } \mathrm{q}=\mathrm{ql} \text { x k } \\
\text { waktu siklus, } \mathrm{Cm}\end{array}$ & $\mathrm{q}$ & & 0,728 & $\mathrm{~m}^{3}$ \\
\hline & $\mathrm{Cm}=$ waktu gali $+\underset{\text { buang }}{(\text { waktu putar } \mathrm{x} 2)}+$ waktu & $\mathrm{cm}$ & & 24 & detik \\
\hline & Produktivitas per jam $Q=\frac{q \times 3600 \times E}{\mathrm{Cm}}$ & Q & & 88,45 & $\mathrm{~m}^{3} / \mathrm{jam}$ \\
\hline & Kapasitas produksi per hari $\mathrm{Qh}=\mathrm{Tk} \times \mathrm{Q}$ & Qh & & 619,16 & $\mathrm{~m}^{3} /$ hari \\
\hline & Koefisien alat $1: \mathrm{Q}$ & koef & & 0,0113 & $\mathrm{~m}^{3} / \mathrm{jam}$ \\
\hline
\end{tabular}

Sumber : Data Olahan (2019)

Hasil dari perhitungan pada tabel 1. Menunjukkan bahwa kapasitas produksi excavator adalah $88,45 \mathrm{~m}^{3} / \mathrm{jam}$. Jam kerja efektif alat dalam satu hari adalah $7 \mathrm{jam}$, sehingga produktivitas excavator per hari adalah $619,16 \mathrm{~m}^{3} / \mathrm{jam}$.

Tabel 2. Perhitungan Kapasitas Produksi Dump Truck

\begin{tabular}{|c|c|c|c|c|c|}
\hline No & Uraian & Kode & Koef & Kuantitas & Satuan \\
\hline \multirow[t]{6}{*}{1} & Input Data & & & & \\
\hline & Jarak quary ke lokasi pekerjaan & $\mathrm{L}$ & & 11 & $\mathrm{Km}$ \\
\hline & Tebal timbunan & $\mathrm{t}$ & & 0,5 & $\mathrm{~m}$ \\
\hline & Berat isi tanah lepas (tabel 2.1) & $\mathrm{D}$ & & 1,2 & Ton $/ \mathrm{m}^{3}$ \\
\hline & Kapasitas Excavator & Qecv & & 88,45 & $\mathrm{~m}^{3} / \mathrm{jam}$ \\
\hline & Jam kerja per hari & $\mathrm{Tk}$ & & 7 & Jam \\
\hline \multirow[t]{13}{*}{2} & alat berat Dump Truck & & & & \\
\hline & kapasitas Dump Truck & $\mathrm{V}$ & & 24 & Ton $/ \mathrm{m}^{3}$ \\
\hline & Faktor efesiensi alat & $\mathrm{Fa}$ & 0,83 & & \\
\hline & Kecepatan rata-rata muatan & V1 & & 30 & $\mathrm{Km} / \mathrm{jam}$ \\
\hline & Kecepatan rata-rata kosong & $\mathrm{V} 2$ & & 40 & $\mathrm{Km} / \mathrm{jam}$ \\
\hline & Waktu siklus, $\mathrm{T} 1+\mathrm{T} 2+\mathrm{T} 3+\mathrm{T} 4$ & Ts & & 54,07 & menit \\
\hline & Waktu memuat, (Vx60) : (D x QEvc) & $\mathrm{T} 1$ & & 13,57 & menit \\
\hline & Waktu tempuh isi, (L: v1) x 60 & $\mathrm{~T} 2$ & & 22 & menit \\
\hline & Waktu tempuh kosong, (L: v2) x 60 & $\mathrm{~T} 3$ & & 16,5 & menit \\
\hline & Waktu lain-lain & $\mathrm{T} 4$ & & 2 & menit \\
\hline & Kapasitas produksi per jam $Q=\frac{V x E_{a} x 60}{D x T_{S}}$ & Q & & 18,42 & $\mathrm{~m}^{3} / \mathrm{jam}$ \\
\hline & Kapasitas produksi per hari, Tk x Q & Qh & & 128,95 & $\mathrm{~m}^{3} /$ hari \\
\hline & Koefisien alat, $1: \mathrm{Q}$ & Koef & & 0,054 & $\mathrm{~m}^{3} /$ hari \\
\hline
\end{tabular}

Sumber : Data Olahan (2019) 
Hasil perhitungan pada tabel 2. Menunjukkan bahwa kapasitas dump truck yang digunakan adalah 18,42 $\mathrm{m}^{3} / \mathrm{jam}$. Jam kerja efektif alat dalam satu hari adalah 7 jam kerja, sehingga produktivitas satu dump truck per hari adalah $128,95 \mathrm{~m}^{3} /$ hari.

Tabel 3. Waktu Pengerjaan Alat Berat (Volume timbunan 1897,81 $\mathbf{~ m}^{3}$ )

\begin{tabular}{ccccccc}
\hline No & $\begin{array}{c}\text { Nama alat } \\
\text { berat }\end{array}$ & $\begin{array}{c}\text { Jumlah alat } \\
\text { berat } \\
\text { (dilokasi) }\end{array}$ & $\begin{array}{c}\text { Produktivitas } \\
\text { Alat }\left(\mathrm{m}^{3} / \text { hari }\right)\end{array}$ & $\begin{array}{c}\text { Total Produktivitas } \\
\text { alat berat }\left(\mathrm{m}^{3} / \text { hari) }\right.\end{array}$ & $\begin{array}{c}\text { Waktu kerja } \\
\text { (hari) }\end{array}$ & $\begin{array}{c}\text { Waktu kerja } \\
\text { (hari) }\end{array}$ \\
\hline$(1)$ & $(2)$ & $(3)$ & $(4)$ & $(5)=(4) \times(3)$ & $(6)=(4 / 5)$ & $(7)$ \\
\hline 1 & Excavator & 1 & 619,16 & 619,16 & 3,07 & 3 \\
2 & Dump Truck & 2 & 128,95 & 257,90 & 7,36 & 8 \\
& & & \multicolumn{2}{c}{ Total waktu pekerjaan } & Hari & 8 \\
\hline
\end{tabular}

Sumber : Data Olahan (2019)

Hasil perhitungan pada tabel 3. Menunjukkan lama waktu pekerjaan yang berbeda untuk excavator dan dump truck. Excavator membutuhkan waktu 3 hari untuk menyelesaikan timbunan pilihan sebanyak 1897,81 $\mathrm{m}^{3}$. Sedangkan dump truck membutuhkan waktu 8 hari kerja, karena kedua alat tersebut saling terkait maka total lama pengerjaan timbunan pilihan oleh kedua alat tersebut (1 excavator dan 2 dump truck) adalah 8 hari kerja.

Agar pengerjaan tersebut dapat dioptimalkan maka perlu disesuaikan jam kerja excavator dengan dump truck. Dalam hal ini diperlukan penambahan jumlah dump truck.

Jumlah unit dump truck yang dibutuhkan untuk mengimbangi produktivitas excavator dalam satu hari adalah sebagai berikut :

$$
\begin{aligned}
& \mathrm{m}=\frac{Q}{Q 1 \times n(\text { unit })} \\
& \mathrm{Q}=619,16 \mathrm{~m}^{3} / \mathrm{jam} \\
& \mathrm{Q} 1=128,95 \mathrm{~m}^{3} / \mathrm{jam} \\
& \mathrm{n}=1 \text { (jumlah unit excavator) } \\
& \mathrm{m}=4,80 \approx 5 \text { unit dumptruck. }
\end{aligned}
$$

Tabel 4. Jumlah Hari Kerja Berdasarkan Optimasi Alat Berat

\begin{tabular}{ccccccc}
\hline No & $\begin{array}{c}\text { Nama alat } \\
\text { berat }\end{array}$ & $\begin{array}{c}\text { Jumlah } \\
\text { alat berat }\end{array}$ & $\begin{array}{l}\text { Volume } \\
\text { timbunan }\left(\mathrm{m}^{3}\right)\end{array}$ & $\begin{array}{l}\text { Produktivitas } \\
\text { alat berat } \\
\left(\mathrm{m}^{3} / \text { hari }\right)\end{array}$ & $\begin{array}{c}\text { Waktu kerja } \\
\text { (hari) }\end{array}$ & $\begin{array}{c}\text { Waktu kerja } \\
\text { (pembulatan) } \\
\text { (hari) }\end{array}$ \\
\hline 1 & 2 & 3 & 4 & 5 & $6=4 / 5$ & 7 \\
\hline 1 & Excavator & 1 & 1897,81 & 619,16 & 3,07 & 3 \\
2 & Dump Truck & 5 & 1897,81 & 644,76 & 2,94 & 3 \\
& & & & Total waktu pekerjaan & Hari & Jam \\
\hline
\end{tabular}

\section{Sumber : Data Olahan (2019)}

Hasil perhitungan pada tabel 4. Menunjukkan bahwa pelaksanaan pekerjaan timbunan tanah dengan volume $1.897,81 \mathrm{~m}^{3}$ dapat terselesaikan dengan kurun waktu pekerjaan 3 (tiga) hari atau 21 jam kerja serta dengan kombinasi alat berat 1 unit excavator dan 5 unit dump truck. Selanjutnya dihitung biaya penggunaan alat berat. Komponen biaya pasti dan tidak pasti/ operasional yang digunakan sesuai dengan yang digunakan pada pekerjaan Peningkatan Akses Jaringan Pipa Air Bersih Kabupaten Tanjung Jabung Barat. 
Optimasi Alat Berat pada Pemindahan Tanah Mekanis (Studi Kasus Penyediaan Timbunan Tanah Pilihan Pada Pekerjaan Peningkatan Akses Jaringan Pipa Air Bersih Kabupaten Tanjung Jabung Barat, Booster Senyerang)

Tabel 6. Perhitungan Biaya Pasti (G)

\begin{tabular}{|c|c|c|c|c|c|c|c|c|}
\hline \multirow{4}{*}{$\begin{array}{c}\text { Nama Alat } \\
\text { Berat }\end{array}$} & \multirow[b]{2}{*}{$\begin{array}{c}\text { Harga } \\
\text { alat } \\
\text { berat } \\
\text { (juta } \\
\text { rp.) } \\
\end{array}$} & \multirow[b]{2}{*}{$\begin{array}{l}\text { Umur } \\
\text { alat } \\
\text { berat } \\
\text { (Thn) }\end{array}$} & \multirow[b]{2}{*}{$\begin{array}{c}\text { Jam Kerja } \\
\text { alat berat per } \\
\text { tahun (Jam) }\end{array}$} & \multicolumn{4}{|c|}{ Komponen Biaya pasti alat berat } & \multirow[b]{2}{*}{$\begin{array}{l}\text { Biaya pasti } \\
\text { alat berat per } \\
\text { jam (Rp.) }\end{array}$} \\
\hline & & & & $\begin{array}{l}\text { Nilai Sisa } \\
\text { alat berat } \\
\text { (juta rp.) }\end{array}$ & $\begin{array}{c}\text { Faktor } \\
\text { Angsura } \\
\text { n Modal }\end{array}$ & $\begin{array}{c}\text { Biaya } \\
\text { Pengembalia } \\
\text { n Modal } \\
\text { (Rp.) }\end{array}$ & $\begin{array}{l}\text { Biaya } \\
\text { Asuransi } \\
\text { (Rp.) }\end{array}$ & \\
\hline & & & & $\mathrm{C}=10 \%$ & & & & \\
\hline & $\mathrm{B}$ & A & $\mathrm{W}$ & $\mathrm{B}$ & $\mathrm{D}$ & $\mathrm{E}$ & $\mathrm{F}$ & $\mathrm{G}=\mathrm{E}+\mathrm{F}$ \\
\hline Excavator & 1.350 & 5 & 2.000 & 135 & 0,19901 & $120.898,51$ & $1.350,00$ & $122.248,51$ \\
\hline Dump truck & 822 & 5 & 2.000 & 82,2 & 0,19901 & $73.613,76$ & 822,00 & $74.435,76$ \\
\hline
\end{tabular}

Sumber : Data Olahan (2019)

Tabel 6. Perhitungan Biaya Tak Pasti / Operasional (P)

\begin{tabular}{|c|c|c|c|c|c|c|c|c|c|c|}
\hline \multirow{2}{*}{ 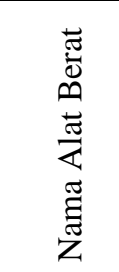 } & \multirow{2}{*}{ 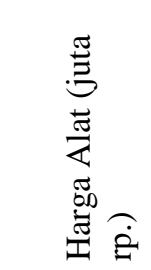 } & \multirow{2}{*}{\multicolumn{2}{|c|}{ 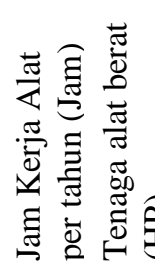 }} & \multicolumn{2}{|c|}{$\begin{array}{l}\text { Biaya Bahan bakar } \\
\text { dan pelumas (Rp.) }\end{array}$} & \multicolumn{2}{|c|}{$\begin{array}{c}\text { Biaya Bengkel } \\
\text { dan Perbaikan (Rp.) }\end{array}$} & \multicolumn{2}{|c|}{$\begin{array}{c}\text { Upah } \\
\text { (Rp.)/jam }\end{array}$} & \multirow{2}{*}{ 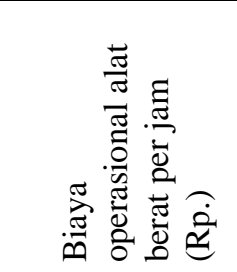 } \\
\hline & & & & 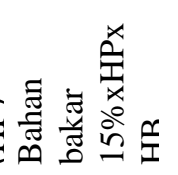 & 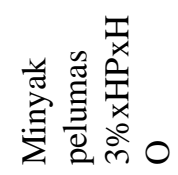 &  & 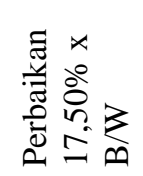 & 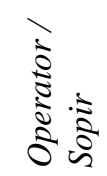 & 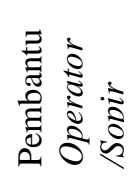 & \\
\hline & B & $\mathrm{W}$ & HP & $\mathrm{H}$ & I & $\mathbf{J}$ & K & $\mathrm{L}$ & M & $\begin{array}{c}\mathrm{P}= \\
\mathrm{H}+\mathrm{I}+\mathrm{J}+\mathrm{K}+\mathrm{L}+\mathrm{M}\end{array}$ \\
\hline $\begin{array}{l}\text { Excava } \\
\text { tor }\end{array}$ & 1.350 & $\begin{array}{c}2.0 \\
00\end{array}$ & $\begin{array}{c}16 \\
8\end{array}$ & 327.600 & 201.600 & 59.063 & 118.125 & $\begin{array}{c}16.50 \\
0\end{array}$ & $\begin{array}{c}13.50 \\
0\end{array}$ & $736.387,50$ \\
\hline $\begin{array}{l}\text { Dump } \\
\text { truck }\end{array}$ & 822 & $\begin{array}{c}2.0 \\
00\end{array}$ & $\begin{array}{c}26 \\
0\end{array}$ & 507,000 & 312.000 & 35.963 & 71.925 & $\begin{array}{c}11.50 \\
0\end{array}$ & $\begin{array}{c}10.27 \\
5\end{array}$ & $948.662,50$ \\
\hline
\end{tabular}

\section{KETERANGAN :}

1 Suku Bunga

2 Upah Operator

3 Upah Pemb.Operator

4 Upah Sopir

5 Upah Pemb.Sopir

6 Harga Bahan Bakar Solar (HB)

7 Minyak Pelumas (HO)

Sumber : Data Olahan (2019)
$: 10$

$\% \quad$ per tahun

: Rp. $16.500 \quad$ per orang per jam

: Rp. 13.500 per orang per jam

: Rp. $11.500 \quad$ per orang per jam

: Rp. 10.275 per orang per jam

: Rp. $13.000 \quad$ per Liter

: Rp. $40.000 \quad$ per Liter

Hasil perhitungan pada tabel 6. Dapat dilihat bahwa perhitungan biaya operasional per unit dan per jam alat berat $(\mathrm{P})$ sebagai berikut :
a. Excavator, dengan biaya operasional sebesar
Rp. 736.387,50/jam

b. Dump truck, dengan biaya operasional sebesar Rp. 948.662,50/jam

Tabel 7. Perhitungan Harga Satuan Dasar Alat Sesuai Keadaan Di Lapangan

\begin{tabular}{|c|c|c|c|c|c|c|c|}
\hline \multirow[b]{2}{*}{ No } & \multirow[b]{2}{*}{ Nama alat } & \multirow[b]{2}{*}{$\begin{array}{l}\text { Kebutuhan } \\
\text { alat berat } \\
\text { (unit) }\end{array}$} & \multirow{2}{*}{$\begin{array}{c}\text { Jam } \\
\text { kerja } \\
\text { alat } \\
\text { berat } \\
\text { (jam) }\end{array}$} & \multicolumn{3}{|c|}{ Komponen Biaya sewa alat berat per jam (Rp.) } & \multirow{2}{*}{$\begin{array}{c}\text { Harga sewa alat } \\
\text { berat } \\
(\mathrm{S}) \\
(\mathrm{Rp} .) \\
\end{array}$} \\
\hline & & & & $\begin{array}{c}\text { Biaya pasti } \\
(\mathrm{G})\end{array}$ & $\begin{array}{c}\text { Biaya } \\
\text { operasional } \\
(\mathrm{P}) \\
\end{array}$ & Jumlah & \\
\hline (a) & (b) & (c) & (d) & (e) & (f) & $(g)=(e)+(f)$ & $(\mathrm{h})=(\mathrm{c}) \times(\mathrm{d}) \times(\mathrm{g})$ \\
\hline 1 & Excavator & 1 & 21 & $122.248,51$ & $736.387,50$ & $858.636,01$ & $18.031 .356,21$ \\
\hline \multirow[t]{2}{*}{2} & Dump truck & 2 & 56 & $74.435,76$ & $948.662,50$ & $1.023 .098,26$ & $114.587 .005,12$ \\
\hline & & & & & Total bic & sewa alat berat & $132.618 .361,33$ \\
\hline
\end{tabular}

Sumber : Data Olahan (2019)

Hasil perhitungan pada tabel 7 menunjukkan total biaya sewa sebesar Rp. 132.618.361,33 
Optimasi Alat Berat pada Pemindahan Tanah Mekanis (Studi Kasus Penyediaan Timbunan Tanah Pilihan Pada Pekerjaan Peningkatan Akses Jaringan Pipa Air Bersih Kabupaten Tanjung Jabung Barat, Booster Senyerang)

Tabel 8. Perhitungan Optimasi Harga Satuan Dasar Alat (S)

\begin{tabular}{|c|c|c|c|c|c|c|c|}
\hline \multirow[b]{2}{*}{ No } & \multirow[b]{2}{*}{ Nama alat } & \multirow{2}{*}{$\begin{array}{l}\text { Kebutuhan } \\
\text { alat berat } \\
\text { (unit) }\end{array}$} & \multirow[b]{2}{*}{$\begin{array}{c}\text { Jam kerja alat berat } \\
\text { (jam) }\end{array}$} & \multicolumn{3}{|c|}{ Komponen Biaya sewa alat berat per jam (Rp.) } & \multirow{2}{*}{$\begin{array}{c}\text { Harga sewa alat berat } \\
\text { (S) } \\
\text { (Rp.) }\end{array}$} \\
\hline & & & & $\begin{array}{l}\text { Biaya pasti } \\
\text { (G) }\end{array}$ & $\begin{array}{l}\text { Biaya operasional } \\
\text { (P) }\end{array}$ & Jumlah & \\
\hline (a) & (b) & (c) & (d) & (e) & (f) & $(g)=(e)+(f)$ & $(\mathrm{h})=(\mathrm{c}) \times(\mathrm{d}) \times(\mathrm{g})$ \\
\hline 1 & Excavator & 1 & 21 & $122.248,51$ & $736.387,50$ & $858.636,01$ & $18.031 .356,21$ \\
\hline 2 & Dump truck & 5 & 21 & $74.435,76$ & $948.662,50$ & $1.023 .098,26$ & $107.425 .317,30$ \\
\hline \multicolumn{7}{|c|}{ Total biaya sewa alat berat } & $125.456 .673,51$ \\
\hline
\end{tabular}

Sumber : Data Olahan (2019)

Hasil perhitungan pada tabel 8. Dapat dilihat bahwa perhitungan biaya sewa alat berat (S) setelah dioptimalkan adalah Rp. 125.456.673,51

\section{SIMPULAN}

Berdasarkan analisa dan hasil penelitian pada pekerjaan Peningkatan Akses Jaringan Pipa Air Bersih Kabupaten Tanjung Jabung Barat, diperoleh kesimpulan antara lain :

1. Produktivitas 1 unit excavator yaitu $88,45 \mathrm{~m}^{3} / \mathrm{jam}$ atau $619,16 \mathrm{~m}^{3} / \mathrm{hari}$. Sedangkan produktivitas 1 unit dumptruck yaitu $18,42 \mathrm{~m}^{3} / \mathrm{jam}$ atau $128,95 \mathrm{~m}^{3} /$ hari.

2. Berdasarkan alat yang tersedia dilapangan 1 unit excavator dan 2 unit dumptruck, maka diperlukan waktu penyelesaian pekerjaan adalah 8 hari. Dimana jam kerja dumptruck adalah 56 jam dan excavator 21 jam.

3. Setelah dioptimasi berdasarkan produktivitas 1 unit excavator diperoleh jumlah dumptruck yang dibutuhkan sebanyak 5 unit dumptruck dengan total waktu pelaksanaan adalah 3 hari (21 jam kerja).

4. Hasil optimasi penggunaan alat berat dari kombinasi 1 excavator dan 2 dumptruck menjadi 1 excavator dan 5 dumptruck menghasilkan pengurangan biaya sewa sebesar Rp.132.618.361,33 - Rp.125.456,51 = Rp. 7.161.687,82

\section{DAFTAR PUSTAKA}

Anonim Informasi Spesifikasi Alat Berat Excavator (http://www.hexindo-tbk.co.id) diakses pada 20 Desember 2018

Anonim Informasi Spesifikasi Dump Truck (http://www.hino.co.id) diakses pada 16 Oktober 2018)

Fatena Susy R. (2002), “ Alat-alat Berat Untuk Proyek Konstruksi”, Rineka Cipta, Jakarta

Fatena Susy R. (2008), “ Alat-alat Berat Untuk Proyek Konstruksi Edisi Kedua”, Rineka Cipta, Jakarta

Maharani, Leny dan Fajarwati. (2006), "Analisis Optimasi Percepatan Durasi Proyek Dengan Metode Least Cost Analysis".

Peraturan Menteri Pekerjaan Umum dan Perumahan Rakyat, (2016). Analisis Harga Satuan pekerjaan Umum. Jakarta: Kementerian Pekerjaan Umum dan Perumahan Rakyat

Rochmanhadi. (1985). Perhitungan Biaya Pelaksanaan Pekerjaan Dengan Menggunakan Slat-Alat Berat. Jakarta : Departemen Pekerjaan Umum

Rochmanhadi, (1992), “ Alat-alat Berat Dan Penggunaannya”, Badan Penerbit Pekerjaan Umum, Jakarta

Rostiyanti. (1999), “Produktivitas Alat Berat Pada Proyek Konstruksi”, Rineka Cipta, Jakarta

Soeharto I, (1995), “Manajemen Proyek Dari Konseptual Sampai Operasional”, Erlangga", Jakarta

Tenriajeng,A.T.2003. Diktat Kuliah Pemindahan Tanah Mekanis, Gunadarma Cipta, Jakarta.

Wilopo, Djoko. (2009), Metode Konstruksi Dan Alat-Alat Berat. Jakarta : Universitas Indonesia (UI-Press) 